\title{
IMPORTANCE OF SMALL DIAMETER WOODY PLANTS AND TREELET SPECIES IN TROPICAL WET EVERGREEN FOREST OF SOUTHERN WESTERN GHATS, INDIA
}

\author{
K. A. Sreejith ${ }^{1}$, M.S. Sanil ${ }^{1}$, T.S. Prasad ${ }^{1}$, M. P. Prejith ${ }^{1}$, V.B. Sreekumar ${ }^{2}$, Akhil Murali $^{1 *}$ \\ ${ }^{1}$ Department of Forest Ecology, Forest Ecology and Biodiversity Conservation Division, Kerala \\ Forest Research Institute-Peechi, Thrissur 680653, Kerala, India \\ ${ }^{2}$ Department of Forest Botany, Forest Ecology and Biodiversity Conservation Division, Kerala \\ Forest Research Institute-Peechi, Thrissur 680653, Kerala, India \\ *akhilmurali7100@gmail.com
}

\begin{abstract}
Tropical forests have long been accepted for their productivity and ecosystem services on account of their high diversity and stand structural attributes. In spite of their significance, tropical forests, and especially those of Asia, remain understudied. Until recently, most forest inventories in Asia have concentrated on trees $10 \mathrm{~cm}$ in diameter. Floristic composition, plant species diversity, above ground biomass, basal area and diversity were investigated across different life form and two-diameter classes in a large scale 10-ha plot, in the undisturbed tropical seasonal rain forest of Southern Western Ghats, Kerala, India. Regeneration pattern of the study area was examined by evaluating fisher's alpha and IVI (Important Value Index) across three layer of vegetation (seedling, sapling, and tree). Within the plot, we recorded 25,390 woody plant species $\geq 1 \mathrm{~cm}$ dbh from 45 families, 91 genera, and 106 species. Plant density was 2539 woody individuals per hectare, with a basal area of $47.72 \mathrm{~m}^{2} /$ ha and an above-ground biomass of 421.77 Mg/ha. By basal area, density, and frequency, the Rubiaceae, Sapotaceae, and Malvaceae families were the most important. Small-diameter trees $(1 \mathrm{~cm} \leq \mathrm{dbh} \leq 10 \mathrm{~cm})$ found to be 78 percent of the total tree population, 20.2 percent of the basal area, and 1.4 percent of the aboveground biomass. They also possessed 6 percent more diversity at the family level, $10 \%$ more diversity at the genus level, and $12 \%$ more diversity at the species level than woody individuals under $10 \mathrm{~cm}$ dbh.. Woody individuals of treelets life form and small-diameter classes were much more diverse and dense than the other groups, indicating that results based only on larger canopy trees and larger diameter class may be not an appropriate representation of the diversity status of a particular tropical forest type. Lower density of individuals in initial girth class indicates the vulnerability of the forest system to anthropogenic, natural disturbance and a changing climate. Reduce the minimum diameter limit down to $1 \mathrm{~cm}$, in contrast to $10 \mathrm{~cm}$ limit
\end{abstract}


used in most of the evergreen forest inventories, revealed a high density and diversity in thelower stories.

Keywords: Permanent plot; Tropical forest; diversity; Life form; Regeneration Dynamics

\section{Introduction}

The broad objectives of long-term research are to investigate composition, structure, and dynamics of forest ecosystem on a spatiotemporal scale. Studies from these plots have provided a better understanding of the functioning of the different ecosystems and the knowledge gained is essential for the conservation needs of the ecosystem and strengthening global capacity for forest science research (Condit 1995, Davies et al .2021). Tropical forests are the richest biological communities on earth and these forests have been recognized to harbour a significant proportion of global biodiversity. The consistent positive relationships between stand structural attributes have been reported across moist wet and dry tropical forests (Duran et al. 2015). Stand structural attributes like tree density and tree average diameter had strong positive relationships with above-ground biomass at all spatial scales (Poorter et al. 2015).

Modal plots of majority of plot networks follow $10 \mathrm{~cm}$ dbh as the minimum dbh (Blundo et al. 2021). This makes the smaller diameter woody individuals as an overlooked population. Importance of large diameter trees have been studied across various plots (Lutz, J.A. et al. 2021, Bradford and Murphy 2019) The ecological importance of small diameter woody plants to the structure and diversity was determined in tropical evergreen forest at Rabi, Gabon (Memiaghe 2016).

Understory layer is important for the nutrient cycling, biodiversity and regeneration capacity of a tropical forest. Dominant early signals of potential long-term forest responses to climate change are available from studies of understory vegetation there is little information about particularities of diversity, stand structure of understory component of tropical moist forest than higher canopy layer (Claudia and Bryan 2011). In this study, we need to determine the stand structure, diversity and composition of woody plants of different height classes to evaluate the relative contribution of each height class

The Western Ghats is one of the hotspots of biodiversity that support an enormous plant wealth. Results of permanent plots from Western Ghats have been published and comparing to other permanent plots the density of plants in the tropical forest system were reported as moderate and reveals the mature stage of stand and good regeneration (Sukumar et al 1992, Ayyappan and Parthasarathy 1999). Data from large-scale permanent plots of wet evergreen 
forests of Western Ghats are still lacking which gives an insight on the diversity of species and the distribution of structural features involved in carbon storage and other ecosystem activities. Here our objective is to understand and describe the floristic composition, structure, and physiognomy of a 10 ha. Permanent plot and examine the relative contribution of woody plants to the abundance, basal area, aboveground biomass, and diversity especially in terms of diameter and height class. Regeneration assessment was also done by analyzing the data in different diameter classes.

\section{Materials and method}

\section{Study site}

The study was conducted in the tropical wet evergreen forest at Karadishola which falls in the Sholayar forest range coming under Vazhachal forest division Thrissur, Kerala part of Western Ghats located at, N $10.294485^{\circ}$ latitude and, E $76.798551^{\circ}$ longitude (Figure. 1). The study site is situated $130 \mathrm{~km}$ towards East direction from Chalakkudy in Thrissur District Kerala and $45 \mathrm{~km}$ towards west direction from Valparai town, Tamilnadu. The elevation ranges from $900 \mathrm{~m}$ to $950 \mathrm{~m}$ above msl. The site receives rain from the southwest (JuneSeptember) and the northeast (October-December) monsoons. The vegetation is of tropical wet evergreen forest type. Champion and Seth (1968) classified this under west coast tropical evergreen forest and floristically it is an intermediate type between Cullenia-Mesua, Palaquium, and Mesua.Anthropogenic activities in the study area include collection of fuel wood, honey, edible fruits and dammar from Canarium strictum and Vateria indica. 
bioRxiv preprint doi: https://doi.org/10.1101/2021.12 31.474647; this version posted January 2, 2022. The copyright holder for this preprint (which was not certified by peer review) is the author/funder. All rights reserved. No reuse allowed without permission.

Figure. 1 Location map of 10 ha Sholayar LTEO plot in Kerala, India

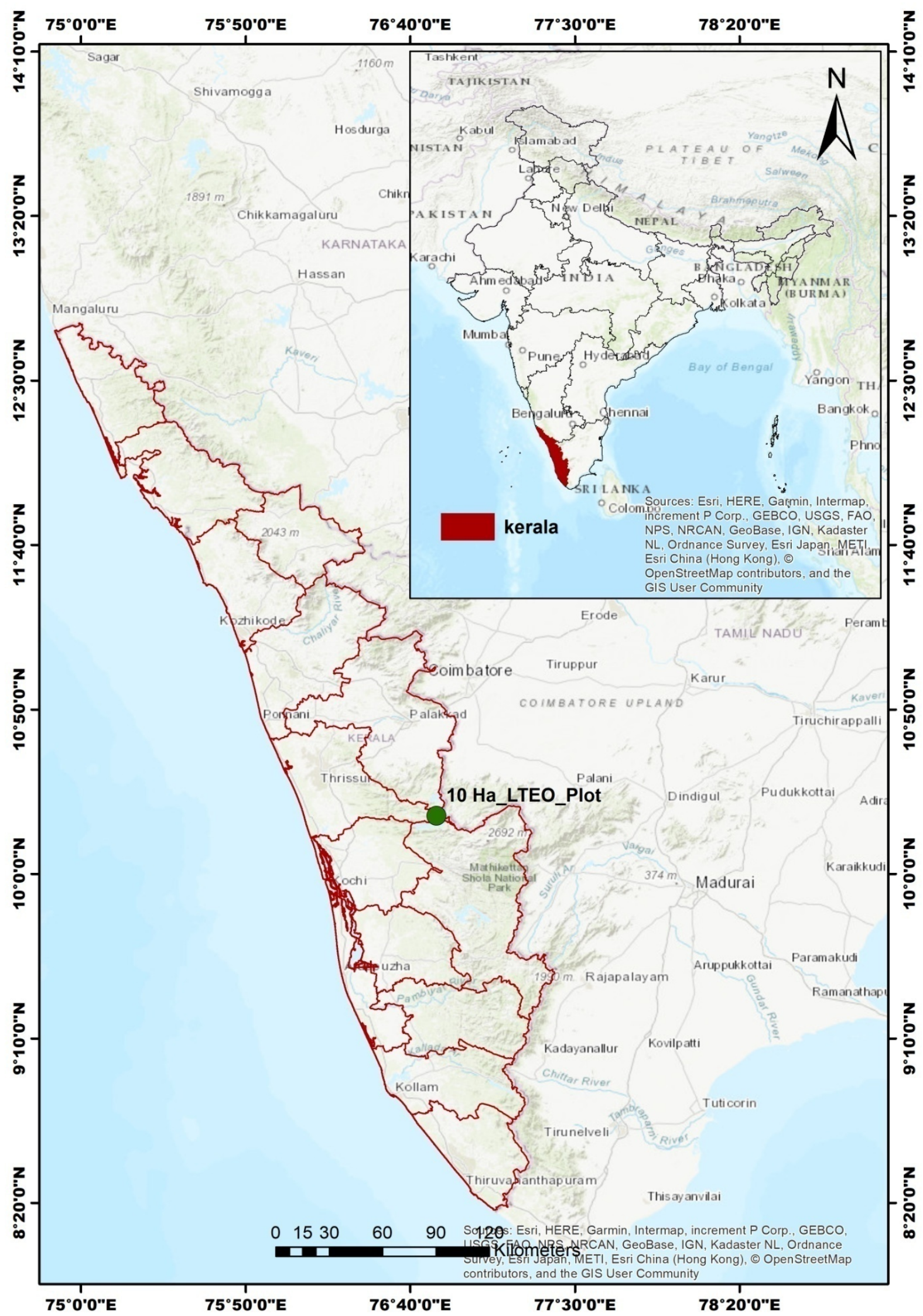




\section{Methodology}

\section{Census}

Field survey methods were in accordance with the standards of the Smithsonian Center for Tropical Forest Science Forest-GEO. We first surveyed the $10 \mathrm{ha}\left(500 \times 200 \mathrm{~m}^{2}\right)$, placing permanent stakes precisely every $20 \mathrm{~m}$ with minimal damage to $\mathrm{t}$ he vegetation (Condit 1998). Subsequently, all woody individuals $\pm 1 \mathrm{~cm}$ diameter-breast-height $(\mathrm{dbh})$ were tagged with numbered aluminum tags, measured, and identified. Stem diameter was measured $1.3 \mathrm{~m}$ above the ground, with swollen or buttressed trees measured at a spot where the trunk was more regular; the measurement spot was painted so future measurements could match. Any stem fork or branch $<1.3 \mathrm{~m}$ above the ground was treated as a secondary stem and measured. Establishment and enumeration (tagging, GBH measurement) of 10 ha plot was carried out from 26 th june 2016 to 28 th December 2018. The individuals were identified using standard floras (Hooker 1872, Gamble and Fischer 1915-1935, Pascal and Ramesh 1987, Sasidharan 2004, Nayar et al. 2014) and identified voucher specimens were deposited in the KFRI herbarium.

\section{Biomass estimation}

The aboveground biomass (AGB) of each individual was estimated using the allometric equation proposed by Chave et al. 2014, defined as:

$\mathrm{AGB}_{\text {est }}=0.0673 \times\left(\rho \mathrm{D}^{2} \mathrm{H}\right)^{0.976}$

where AGB $(\mathrm{kg})$ is the estimated aboveground biomass, DBH $(\mathrm{cm})$ is the diameter of the tree at breast height, $\mathrm{H}(\mathrm{m})$ is the estimated total height, and $\rho\left(\mathrm{g} / \mathrm{cm}^{3}\right)$ is the wood density.

To get wood density, we applied the following standardized protocol: (i) Tree identified to the species level were assigned the corresponding wood density value from the Global Wood Density Database (GWDD) (Chave et al. 2009); (ii) When a species was identified at the genus, we used the average density of wood for all species of the same genus in the database and (iii) When trees with no botanical identification or that were not present in the GWDD we used the average density of wood for all species in the plot (Herault and Camille 2018)

Tree height was retrieved by applying the local Height-Diameter (H-D) models; we also used an unpublished dataset of tree height and diameter from an evergreen forest of Southern 
Western Ghats. After comparing different local H-D models, we used the method with the lowest residual error to compute the local height-diameter model (Feldpausch et al .2012). Then we retrieved height using this local H-D model. The wood density and height data were retrieved and the aboveground biomass (AGB) was estimated taking all uncertainties into account using the BIOMASS r package (Réjou-Méchain et al. 2017).

\section{Height categories of species}

We classified all species into four growth forms according to their estimated maximum height (Kenfack et al 2007). Treelets and small trees include all species with adult generally less than $10 \mathrm{~m}$ tall; understory trees are those with adults 10-20 m tall; lower canopy species have heights 20-30 m; and upper canopy species are those often $>30 \mathrm{~m}$ in height and emergent above the main canopy. Corresponding adult stem diameters were $<10 \mathrm{~cm}, 10-30$ $\mathrm{cm}, 30-60 \mathrm{~cm}$, and $>60 \mathrm{~cm} \mathrm{dbh}$, respectively. Information on the heights of the species came from field estimates in the plot supplemented with information from the literature (Sasidharan 2012).

\section{Data analysis}

Because in most of the inventories in the tropical forests are included only individuals with $\mathrm{dbh} \geq 10 \mathrm{~cm}$, for comparison we report abundance basal area above ground biomass on a per hectare basis as well as for all 10 ha combined and for diameter classes of both $1 \mathrm{~cm} \leq \mathrm{dbh}$ $<10 \mathrm{~cm}$ and $\geq 10 \mathrm{~cm}$ (Memiaghe et al .2016). Standard deviations of each parameter are obtained by dividing the $500 \times 200 \mathrm{~m}^{2}$ into 10 non-overlapping $100 \times 100 \mathrm{~m}^{2}$ and counting individuals on each. Our counts on individual do not include multiple stems per tree, but multiple stems are included in the basal area calculations..To provide quantitative estimates of plant diversity, fishers alpha, Shannon's Index Hand Simpson's index were used. Twosided, paired t-test was used to test the difference of species diversity indices, biomass, basal area, density between plants with $d b h<\mathbf{1 0} \mathbf{c m}$ and $\geq \mathbf{1 0} \mathbf{c m}$. The means of basal area, genera, species and stem per hectare were also calculated for the four life form in each sub plot. Oneway analysis of variance (ANOVA) was used to test the differences between the means of these parameters using $\mathrm{R}$ package. 


\section{Regeneration assessment}

Regeneration status was assessed by evaluating the girth class categories and the categories of trees were based on the girth class of individuals. $>30 \mathrm{~cm}$ at gbh (girth at breast height) were considered as trees, 10-30 $\mathrm{cm}$ gbh as saplings and $<10 \mathrm{~cm}$ gbh as seedlings(Sushil.2016) . The vegetation data were quantitatively analyzed for relative density, relative frequency and relative dominance based on which Important value index(IVI) (Curtis \&McIntosh, 1950) was estimated.. Regeneration was characterized with density and dominance. While density is the number of recruits (seedlings and/ or saplings according to the context) in a unit area (SushilSaha .2016). For comparing the diversity species richness and Fisher's $\alpha$ value were calculated for seedling, sapling and tree. The trees were further divided into seven girth classes i.e. class 30-60, 60-90, 90-120, 120-150, 150-180, 180-210, 210-240>240 for density and girth class distribution of trees.

\section{Results}

\section{Woody floristic structure and diversity}

We observed 106 morphospecies inside the 10-ha plot, of which 95 (85.2\%) were recognized to species and the remaining $11(14.8 \%)$ to genus level. The 106 morphospecies belongs to 45 families and 91 genera. Euphorbiaceae and Lauraceae were the most diverse family with 8 species in 5 genera, trailed by Meliaceae and Rubiaceae that had 8 species in 4 genera and 7 species in 6 genera respectively.

Anacardiaceae (6 species in 5 genera), Rutaceae (6 species in 5 genera) and Phyllanthaceae (6 species in 4 genera) are the other diverse families in the permanent plot. The genera Aglaia and Mallotus were the richest with 5 and 4 species respectively, followed by Litsea, Aporosa, syzygium each with three species.

Altogether the large-diameter group comprised 86 species in 73 genera and 39 families, while 99 species ( $96 \%$ of the total) in 83 genera and 42 families were recorded among smalldiameter trees. In the present study plot 75 species/ha were recorded for all woody individuals, Mean species richness of woody plants was much higher in the small diameter class than that of high diameter class (70 species/ha in class1 and 48 species/ha in cass2) in each plot. Furthermore, the class 1 woody plants are more diverse than the class 2 plants indicated by higher values of other three-diversity index. The shanon diversity index of the class 1 was not significantly higher than class $2(\mathrm{P}=0.02)$ (Table 1). 
(a)

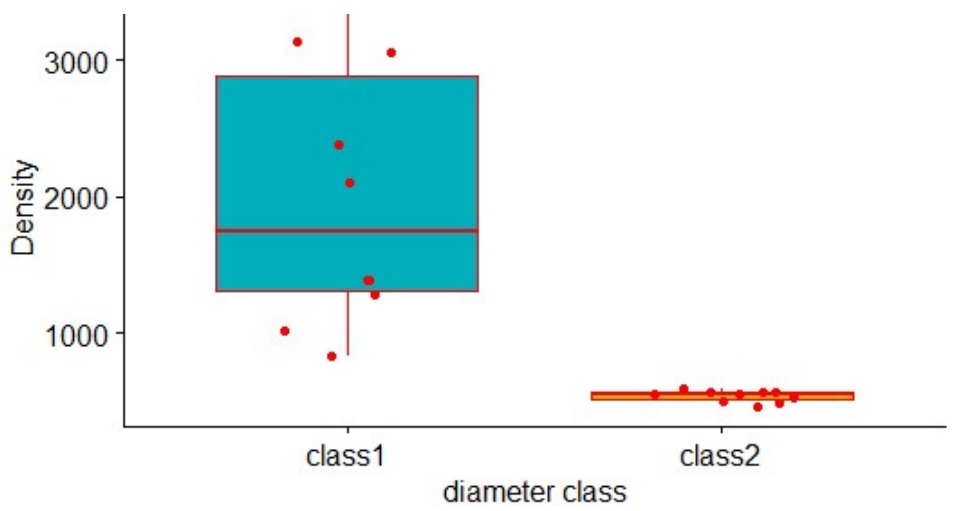

(c)

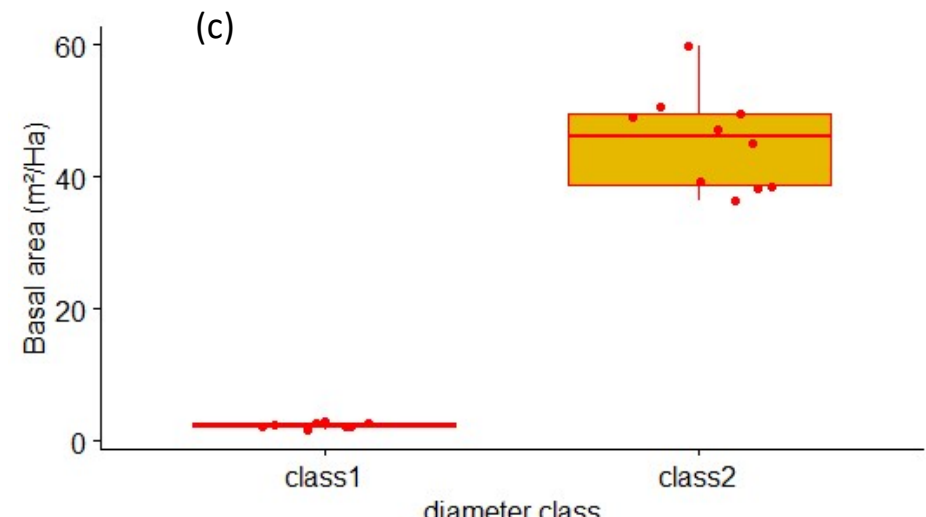

(e)

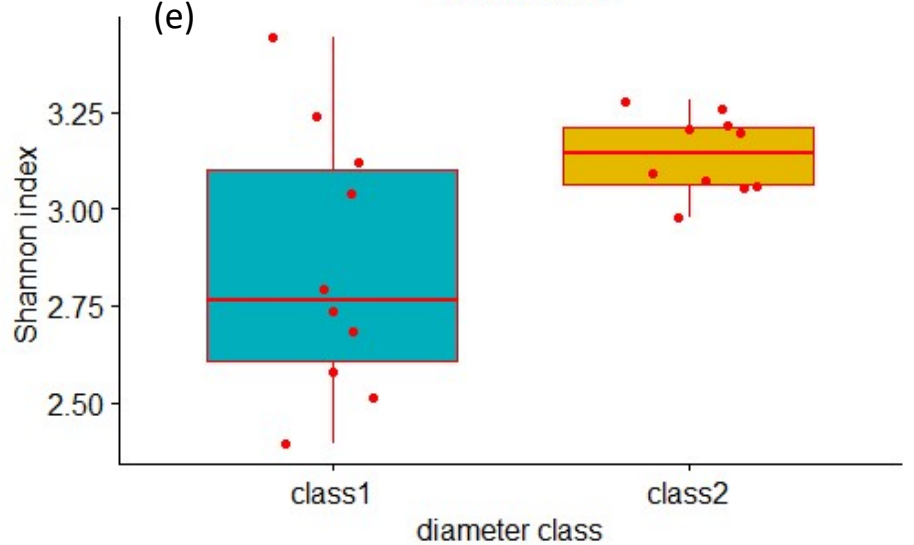

(g)

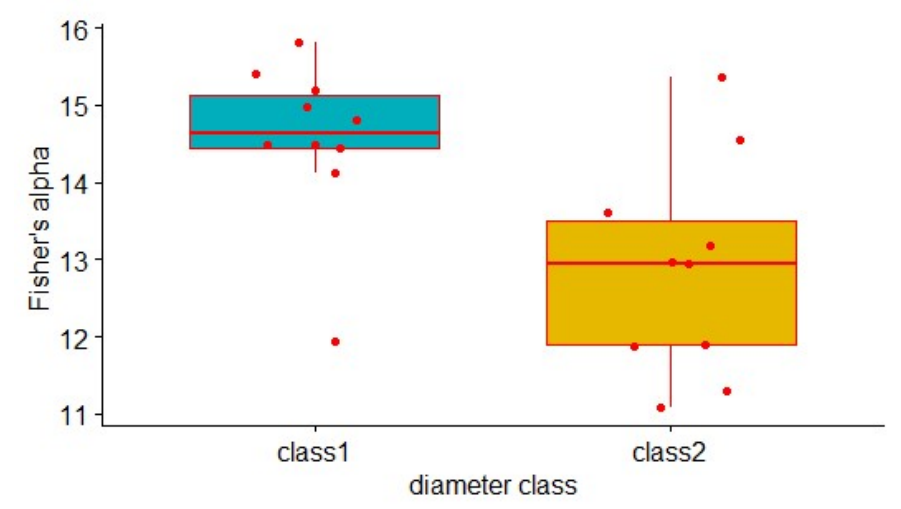

(b)

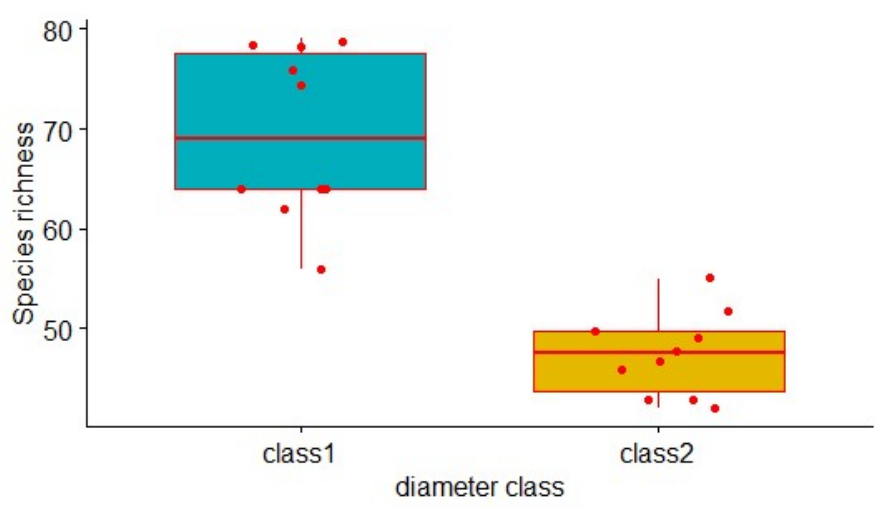

(d)
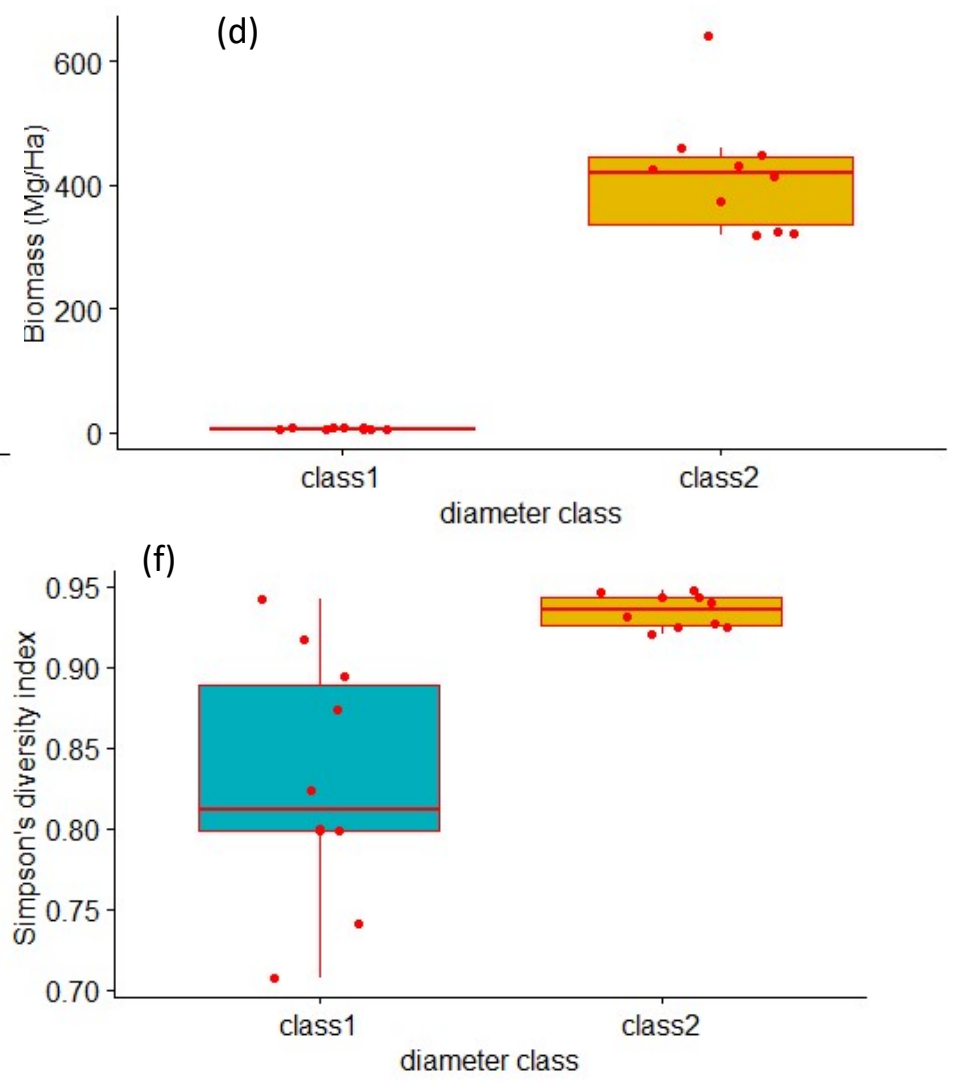

Figure 1: Box plots showing distribution of, density (a), species richness (b), basal area(c), biomass (d), Shannon index (e), Simpson index (f), fisher's alpha ( $g$ ) across two diameter classes 
Table 1: Comparison of the distribution of structure and diversity across small-diameter $(1 \mathrm{~cm} \leq \mathrm{dbh}$ $<10 \mathrm{~cm})$ and large-diameter $(\mathrm{dbh} \geq 10 \mathrm{~cm})$ tree of the sholayar 10 -ha plot. Numbers in parenthesis represent standard deviation or percentages.

\begin{tabular}{|l|l|l|l|}
\hline & $\geq 1 \mathrm{~cm}$ & $<10 \mathrm{~cm}$ & $\geq 10 \mathrm{~cm}$ \\
\hline all families & 45 & 42 & 39 \\
\hline all species & 106 & 99 & 86 \\
\hline all genera & 91 & 83 & 73 \\
\hline All trees & 25390 & 19975 & 5415 \\
\hline total basal area & 477.24 & 23.364 & 453.882 \\
\hline total above ground biomass & 4217.779 & 60.847 & 4156.931 \\
\hline mean density per hector & $2539(975.2)$ & $1997.4(946.57)$ & $541.6(43.97)$ \\
\hline mean number of species per hec & $75.3(8.459)$ & $69.5(8.343)$ & $47.5(4.196)$ \\
\hline mean basal area per hec & $47.724(7.5)$ & $2.336(0.42)$ & $45.38(7.34)$ \\
\hline mean AGB per hec & $421.777(95.93)$ & $6.0847(1.037)$ & $415.693(95.347)$ \\
\hline Shannon diversity index & 3.143 & 2.841 & 3.11 \\
\hline Simpson diversity index & 0.123 & 0.171 & 0.066 \\
\hline fisher's alpha index & 15.542 & 14.56 & 12.87 \\
\hline
\end{tabular}

\section{Abundances}

In the 10-ha plot, a sum of 25390 trees were recorded, with a moderate density of 2539 individuals/ha. Density of woody species in two diameter class varied significantly ( $p$ value $<$ 0.01). Abundance Small-diameter trees was 3.6 times greater than large-diameter trees. There were 19975 small-diameter plants (78.67\% of all stems), averaging 1997 individuals/ha, while large-diameter trees had an abundance of 5415 plants and density of only 546 individuals/ha.. The family Rubiaceae, is the most abundant, with densities $>900$ individuals/ha, followed by Euphorbiaceae, Urticaceae, Sapotaceae, Meliaceae, Malvaceae, and Putranjivaceae. Among tree genera Palaquium, cullenia, of family Sapotaceae and Malvaceae respectively, were the most abundant, with $>100$ individuals/ha, followed by Drypetes, Mesua, Aglaia, Vateria, syzygium and Agrostistachys at species level, Psychotria nudiflora, Palaquium ellipticum, Cullenia exarillata, Vateria indica were the dominant based on IVI value, followed by Mesua ferrea and Dendrocnide sinuate

Table2 : The 20 most dominannt tree species in the 10-ha sholayar plot ranked by IVI. Basal area and AGB rank indicated in parenthesis.

\begin{tabular}{|l|l|l|l|l|}
\hline species & IVI & Abundance & $\begin{array}{c}\text { Basal area } \\
\text { (basal area } \\
\text { rank) }\end{array}$ & $\begin{array}{c}\text { Above Ground } \\
\text { Biomass } \\
\text { (AGB rank) }\end{array}$ \\
\hline Psychotria nudiflora & 35.29 & 8340 & $5.32(16)$ & $17.57(24)$ \\
\hline Palaquium ellipticum & 26.4 & 1257 & $96.05(2)$ & $817.7(2)$ \\
\hline Cullenia exarillata & 25.69 & 1027 & $96.97(1)$ & $1069.7(1)$ \\
\hline
\end{tabular}




\begin{tabular}{|l|l|l|l|l|}
\hline Vateria indica & 14.78 & 605 & $52.82(3)$ & $473.07(4)$ \\
\hline Mesua ferrea & 12.13 & 878 & $35.04(4)$ & $564.73(3)$ \\
\hline Dendrocnide sinuata & 9.529 & 1376 & $13.26(8)$ & $25.89(19)$ \\
\hline Drypetes venusta & 7.616 & 600 & $18.71(6)$ & $138.09(6)$ \\
\hline Dimocarpus longan & 6.928 & 373 & $19.69(5)$ & $194.23(5)$ \\
\hline Drypetes malabarica & 5.545 & 413 & $12.34(9)$ & $95.19(7)$ \\
\hline Agrostistachys borneensis & 5.524 & 594 & $8.846(11)$ & $60.35(11)$ \\
\hline Aglaia tomentosa & 5.35 & 706 & $5.91(15)$ & $33.55(16)$ \\
\hline Myristica malabarica & 4.391 & 362 & $7.8(12)$ & $42.78(13)$ \\
\hline Dysoxylum malabaricum & 4.388 & 390 & $7.25(13)$ & $72.95(8)$ \\
\hline Syzygium laetum & 3.841 & 517 & $2.26(26)$ & $12.64(27)$ \\
\hline Psychotria anamalayana & 3.829 & 604 & $0.57(47)$ & $1.389(55)$ \\
\hline Antidesma montanum & 3.666 & 249 & $6.46(14)$ & $39.45(14)$ \\
\hline Strobilanthes sp & 3.636 & 660 & $0.50(49)$ & $1.313(58)$ \\
\hline Litsea bourdillonii & 3.606 & 328 & $4.69(18)$ & $25(20)$ \\
\hline Croton zeylanicus & 3.415 & 514 & $0.28(57)$ & $0.759(65)$ \\
\hline Ocotea lancifolia & 3.397 & 354 & $3.20(23)$ & $15.96(25)$ \\
\hline
\end{tabular}

\section{Basal Area}

The 10 hectare LTEO plot has total basal area of $477.24 \mathrm{~m}^{2}\left(47.72 \pm 7.58 \mathrm{~m}^{2} / \mathrm{ha}\right), 20 \%$ of the basal area were occupied by Malvaceae $(9.69 \mathrm{~m} 2 / \mathrm{ha})$ and Sapotaceae $\left(9.6 \mathrm{~m}^{2} / \mathrm{ha}\right)$ followed by Dipterocarpaceae, Calophyllaceae, Putranjivaceae and Sapindaceae. The dominant genera by basal area were Cullenia, Palaquium ,Vateria, Mesua, Drypetes, Dimocarpus. At species level, Cullenia exarillata and Palaquium elipticum were the most important followed by Vateria indica, Mesua ferrea, Dimocarpus longan, Drypetes wightii and Holigarna nigra. Small-diameter trees contributed $4.89 \%$ of the total basal area.From the $t$ test, it was found that the difference in the means of basal area among two diameter class were statistically significant at $\mathrm{P} \leq 0.01$.

\section{Aboveground biomass}

Total aboveground biomass of the 10-ha plot was $4217.779 \mathrm{Mg}$, averaging $421.777 \pm 95.93 \mathrm{Mg} / \mathrm{ha}$ for all woody plants of $\geq 1 \mathrm{~cm} \mathrm{dbh}$. Malvaceae is reported to be the family with highest AGB (106.97Mg/ha), followed by Sapotaceae $(81.7 \mathrm{Mg} / \mathrm{ha})$, Calophyllaceae $\quad(57.97 \quad \mathrm{Mg} / \mathrm{ha}), \quad$ Dipterocarpaceae $(47.30781 \mathrm{Mg} / \mathrm{ha}) \quad$ and Putranjivaceae(23.32Mg/ha). Cullenia and Palaquim were the most important genus in the plot (Table 4). Cullenia exarillata was the most important species in terms of aboveground biomass, followed by Palaquim elipticum, Mesua ferrea and Vateria indica. The aboveground biomass was significantly varied among two-diameter classes at $\mathrm{P} \leq 0.01$. AGB 
for large-diameter trees was $415.693 \pm 95.347 \mathrm{Mg} / \mathrm{ha}$. whereas the AGB of small diameter class was $6.0847 \pm 1.037 \mathrm{Mg} /$ ha, approximately $1.29 \%$ of the total biomass (Table 2 )

Table 3: The 20 most abundant tree genera in the 10-ha sholayar plot ranked by density. Basal area and aboveground biomass (AGB) rank indicated in parenthesis.

\begin{tabular}{|l|l|l|l|}
\hline Genus & Abundance & $\begin{array}{l}\text { Basal area }\left(\mathrm{m}^{2}\right) \text { rank in } \\
\text { parenthesis }\end{array}$ & $\begin{array}{l}\text { Biomass (unit) rank in } \\
\text { biomass are in paranthesis }\end{array}$ \\
\hline Psychotria & 8944 & $5.88(18)$ & $18.96(23)$ \\
\hline Dendrocnide & 1376 & $13.26(8)$ & $25.89(19)$ \\
\hline Palaquium & 1257 & $96.05(2)$ & $817.7(2)$ \\
\hline Cullenia & 1027 & $96.97(1)$ & $1069.7(1)$ \\
\hline Drypetes & 1013 & $31.06(5)$ & $233.2(5)$ \\
\hline Mesua & 878 & $35.04(4)$ & $564.7(3)$ \\
\hline Aglaia & 845 & $6.50(15)$ & $37.11(15)$ \\
\hline Strobilanthes & 697 & $0.53(40)$ & $1.40(44)$ \\
\hline Vateria & 605 & $52.82(3)$ & $473 .(4)$ \\
\hline Syzygium & 595 & $3.09(22)$ & $20.05(22)$ \\
\hline Agrostistachys & 594 & $8.84(10)$ & $60.35(11)$ \\
\hline Litsea & 550 & $7.01(14)$ & $35.50(16)$ \\
\hline Croton & 514 & $0.28(46)$ & $0.759(51)$ \\
\hline Aporosa & 404 & $1.12(30)$ & $3.509(39)$ \\
\hline Lasianthus & 396 & $0.32(44)$ & $1.325(46)$ \\
\hline Mallotus & 395 & $5.25(19)$ & $26(18)$ \\
\hline Dysoxylum & 390 & $7.25(13)$ & $72.95(7)$ \\
\hline Myristica & 390 & $8.72(11)$ & $47.5(13)$ \\
\hline Meiogyne & 389 & $1.77(27)$ & $6.55(32)$ \\
\hline Dimocarpus & 373 & $19.69(6)$ & $194.23(6)$ \\
\hline
\end{tabular}

Table 4: The 15 most abundant Plant families in the 10-ha Sholayar plot, ranked by FIV (Family Important value index).

\begin{tabular}{|l|l|l|l|l|l|l|l|l|}
\hline family & species & $\mathrm{D}$ & $\mathrm{Ba}$ & RD & RDo & RDi & FIV & AGB \\
\hline Rubiaceae & 7 & 936.4 & 0.62 & 36.96 & 1.31 & 6.60 & 44.87 & $20.31(20)$ \\
\hline Sapotaceae & 2 & 129 & 9.61 & 5.09 & 20.25 & 1.89 & 27.23 & $817.8(2)$ \\
\hline Malvaceae & 1 & 102.7 & 9.70 & 4.05 & 20.44 & 0.94 & 25.43 & $1069.7(1)$ \\
\hline Euphorbiaceae & 8 & 153.9 & 1.59 & 6.07 & 3.35 & 7.55 & 16.97 & $94.42(8)$ \\
\hline Meliaceae & 8 & 124.1 & 1.38 & 4.90 & 2.90 & 7.55 & 15.35 & $110.12(7)$ \\
\hline Dipterocarpaceae & 1 & 60.5 & 5.28 & 2.39 & 11.13 & 0.94 & 14.46 & $473.07(4)$ \\
\hline Lauraceae & 8 & 97 & 1.13 & 3.83 & 2.38 & 7.55 & 13.76 & $58.46(12)$ \\
\hline Calophyllaceae & 2 & 89.3 & 3.71 & 3.52 & 7.81 & 1.89 & 13.22 & $579.71(3)$ \\
\hline Putranjivaceae & 2 & 101.3 & 3.11 & 4.00 & 6.55 & 1.89 & 12.43 & $233.29(5)$ \\
\hline Urticaceae & 3 & 153.9 & 1.44 & 6.07 & 3.04 & 2.83 & 11.94 & $31.36(16)$ \\
\hline Phyllanthaceae & 6 & 65.7 & 0.83 & 2.59 & 1.75 & 5.66 & 10.00 & $51.49(14)$ \\
\hline Anacardiaceae & 6 & 14.6 & 1.53 & 0.58 & 3.23 & 5.66 & 9.47 & $83.11(9)$ \\
\hline Sapindaceae & 3 & 43.7 & 2.00 & 1.72 & 4.20 & 2.83 & 8.76 & $195.39(6)$ \\
\hline
\end{tabular}




\begin{tabular}{|l|l|l|l|l|l|l|l|l|}
\hline Myrtaceae & 4 & 72.5 & 0.32 & 2.86 & 0.67 & 3.77 & 7.30 & $20.26(21)$ \\
\hline Annonaceae & 4 & 51.8 & 0.29 & 2.04 & 0.62 & 3.77 & 6.44 & $13.40(22)$ \\
\hline Rutaceae & 6 & 12.9 & 0.02 & 0.51 & 0.04 & 5.66 & 6.21 & $0.844(29)$ \\
\hline Myristicaceae & 2 & 39 & 0.87 & 1.54 & 1.84 & 1.89 & 5.26 & $47.57(15)$ \\
\hline Acanthaceae & 2 & 69.7 & 0.05 & 2.75 & 0.11 & 1.89 & 4.75 & $1.409(27)$ \\
\hline Elaeocarpaceae & 2 & 9.5 & 0.81 & 0.37 & 1.72 & 1.89 & 3.98 & $66.30(11)$ \\
\hline Staphyleaceae & 1 & 14.5 & 1.08 & 0.57 & 2.27 & 0.94 & 3.79 & $69.84(10)$ \\
\hline Ebena ceae & 2 & 14.5 & 0.61 & 0.57 & 1.28 & 1.89 & 3.74 & $57.38(13)$ \\
\hline
\end{tabular}

\section{Forest structure by life form}

Species richness varied significantly among the four life form $(\mathrm{p}<0.001)$. Among the 106 species in the Sholayar 10-ha LTEO plot, there were 54 treelet species, with diameters mostly restricted to $<10 \mathrm{~cm}$. These accounted for $60 \%$ of the total number of individuals in the plot, but only $8 \%$ of basal area and $3.5 \%$ of aboveground biomass respectively (Table 2 ). Seven of the 20 most abundant species in the plot were treelets,

The remaining 52 species comprised 19 understory, 16 lower canopy and 17 upper canopy species, all of which reach more than $10 \mathrm{~m}$ in height and $\mathrm{dbh} \geq 10 \mathrm{~cm}$ at maturity. These species represented $40 \%$ of the total number of trees, $92 \%$ of the total basal area and $96.5 \%$ of the total aboveground biomass.

Small-diameter trees included 52 treelets and all upper canopy tree species, as well as 94.73 $\%$ and $85.7 \%$ of understory and lower canopy tree species, respectively. In this diameter size class, treelets accounted for $56.27 \%$ individuals, $8.21 \%$ of the basal area, and $3.45 \%$ of the aboveground biomass. Understory and canopy species accounted for only $22.4 \%$ of all trees, $50.64 \%$ of basal area, and $64.22 \%$ of aboveground biomass in these small-diameter trees, whereas accounting for only $25 \%$ of all trees. There were only 41 species of treelets among trees with dbh $\geq 10 \mathrm{~cm}$, accounting for $17.80 \%$ individuals and a very small fraction of their total basal area and aboveground biomass in this diameter class. Upper canopy species, on the other hand, accounted for 61.97 percent of the basal area and $64.46 \%$ of the aboveground biomass in this diameter class, accounting for $8.93 \%$ of the individual.

Statistical analysis made by one way ANOVA revealed the means of stem density, basal area and biomass among life form in all three groups (all woody plants and both the diameter class) were statistically significant at $\mathbf{P} \leq 0.01$. At all diameter classes, values for mean species richness and fishers alpha were much higher than that of the other three life form indicate the 
more diverse and heterogeneous treelet layer. Furthermore, highest values for Shannon and Simpson diversity index were reported in understory species at both $\geq 1$ and $<10 \mathrm{~cm} d b h$ classes. Both Shannon and Simpson index among four life forms were not statistically significant at larger diameter class $(\mathrm{p}=0.04$ and $\mathrm{p}=0.26$ respectively).

Table 5. Distribution of species richness, density, basal area, Above ground biomass, Shannon index, Simpson index, fishers alpha between tree life forms in different diameter class of woody individuals in the Sholayar plot.

\begin{tabular}{|c|c|c|c|c|c|}
\hline & Treelets & Understory & Lower canopy & Upper canopy & $\mathrm{p}$ value \\
\hline \multicolumn{6}{|c|}{ Species Richness } \\
\hline$\geq 1$ & $36.4 \pm 4.8$ & $15.6 \pm 3$ & $11.3 \pm 1.6$ & $12.2 \pm 1.1$ & $\mathrm{p}<0.01$ \\
\hline$<10 \mathrm{~cm}$ & $33.6 \pm 4.9$ & $14.9 \pm 1.9$ & $11.8 \pm 2.14$ & $8.9 \pm 0.8$ & $\mathrm{p}<0.01$ \\
\hline$\geq 10 \mathrm{~cm}$ & $15.2 \pm 2.4$ & $12.1 \pm 1.85$ & $9.3 \pm 1.4$ & $10.9 \pm 1.1$ & $\mathrm{p}<0.01$ \\
\hline \multicolumn{6}{|l|}{ Density } \\
\hline$\geq 1$ & $\begin{array}{l}1525.1 \pm 82 \\
3\end{array}$ & $275.2 \pm 59$ & $270 \pm 37$ & $468.4 \pm 89.6$ & $\mathrm{p}<0.01$ \\
\hline$<10 \mathrm{~cm}$ & $1428 \pm 832$ & $156.2 \pm 36$ & $142.6 \pm 22.02$ & $270 \pm 84.73$ & $\mathrm{p}<0.01$ \\
\hline$\geq 10 \mathrm{~cm}$ & $96.4 \pm 26.3$ & $119 \pm 27.3$ & $127.7 \pm 225$ & $198.4 \pm 27.6$ & $\mathrm{p}<0.01$ \\
\hline \multicolumn{6}{|c|}{ Basal area } \\
\hline$\geq 1$ & $3.9 \pm 1.5$ & $5.4 \pm 0.93$ & $6.74 \pm 1.5$ & $31.64 \pm 7.4$ & $\mathrm{p}<0.01$ \\
\hline$<10 \mathrm{~cm}$ & $1.15 \pm 0.2$ & $0.33 \pm 0.08$ & $0.34 \pm 0.07$ & $0.50 \pm 0.1$ & $\mathrm{p}<0.01$ \\
\hline$\geq 10 \mathrm{~cm}$ & $2 . .7 .6 \pm 1.1$ & $5.07 \pm 0.90$ & $6.39 \pm 1.52$ & $31.14 \pm 7.4$ & $\mathrm{p}<0.01$ \\
\hline \multicolumn{6}{|c|}{ Above ground biomass } \\
\hline$\geq 1$ & $14.38 \pm 5.1$ & $42.9 \pm 9$ & $45.98 \pm 11.8$ & $318.4 \pm 96.2$ & $\mathrm{p}<0.01$ \\
\hline$<10 \mathrm{~cm}$ & $2.26 \pm 0.47$ & $1.19 \pm 0.34$ & $1.09 \pm 0.24$ & $1.52 \pm 0.40$ & $\mathrm{p}<0.01$ \\
\hline$\geq 10 \mathrm{~cm}$ & $12.12 \pm 5.15$ & $41.72 \pm 8.9$ & $44.88 \pm 11.71$ & $316 \pm 96.2$ & $\mathrm{p}<0.01$ \\
\hline \multicolumn{6}{|c|}{ Shannon index } \\
\hline$\geq 1$ & $2 \pm 0.3$ & $2.2 \pm 0.1$ & $1.87 \pm 0.2$ & $1.85 \pm 0.1$ & $\mathrm{p}<0.01$ \\
\hline$<10 \mathrm{~cm}$ & $1.90 \pm 0.28$ & $2.13 \pm 0.14$ & $1.81 \pm 0.18$ & $1.80 \pm 0.07$ & $\mathrm{p}<0.01$ \\
\hline$\geq 10 \mathrm{~cm}$ & $1.87 \pm 0.28$ & $1.92 \pm 0.09$ & $1.69 \pm 0.22$ & $1.74 \pm 0.08$ & $\mathrm{p}=0.04$ \\
\hline \multicolumn{6}{|c|}{ Simpson index } \\
\hline$\geq 1$ & $0.698 \pm 0.1$ & $0.857 \pm 0$ & $0.814 \pm 0$ & $0.8 \pm 0$ & $\mathrm{p}<0.01$ \\
\hline$<10 \mathrm{~cm}$ & $0.66 \pm 0.1$ & $0.83 \pm 0.04$ & $0.78 \pm 0.03$ & $0.80 \pm 0.01$ & $\mathrm{p}<0.01$ \\
\hline$\geq 10 \mathrm{~cm}$ & $0.738 \pm 0.1$ & $0.8 \pm .03$ & $0.76 \pm 0.07$ & $0.75 \pm 0.04$ & $\mathrm{p}=0.26$ \\
\hline \multicolumn{6}{|c|}{ Fishers alpha } \\
\hline$\geq 1$ & $6.93 \pm 0.6$ & $4.06 \pm 0.5$ & $2.39 \pm 0.4$ & $2.28 \pm 0.2$ & $\mathrm{p}<0.01$ \\
\hline$<10 \mathrm{~cm}$ & $6.4 \pm 0.6$ & $4.08 \pm 0.4$ & $2.43 \pm 0.5$ & $2.29 \pm 0.2$ & $\mathrm{p}<0.01$ \\
\hline$\geq 10 \mathrm{~cm}$ & $5.23 \pm 1.15$ & $3.38 \pm 0.5$ & $2.32 \pm 0.42$ & $2.48 \pm 0.31$ & $\mathrm{p}<0.01$ \\
\hline
\end{tabular}

\section{Pattern of regeneration}

\section{Tree layer}

Tree layer is remarked by a total of 59 species and Fisher's $\alpha$ for this group is 9.426. Based on the IVI value Palaquium elipticum was reported dominant species followed by Cullenia 
exarillata and Vateria indica. The maximum values of frequency and density were recorded for Palaquim elipticum followed by Cullenia exarillata and Drypetes venusta. The maximum values of total basal cover were also observed for Cullenia exarillata followed by Palaquim elipticum and vateria indica.

\section{Sapling layer}

Total 54 species and a Fisher's $\alpha$ value of 9.05 is reported from sapling layer, the higher value for IVI was reported for Aglaia tomentosa followed by Cullenia exarillata and Mesua ferrea. The IVI value for Palaquium ellipticum and Vateria indica place them fourth and fifth rank respectively among saplings of all tree species.

\section{Seedling layer}

In seedling layer contains only 50 species and have Fisher's $\alpha$ value of 8.71 . This layer is remarked with high dominance of Mesua ferrea followed by Syzygium laetum and Dysoxylum malabaricum but the species Cullenia exarillata and Palaquium ellipticum have comparatively lower IVI in this class.

Table 6: IVI values of the15 dominant species in seedling, sapling and tree class.

\begin{tabular}{llll}
\hline Species & Seedling & Sapling & Tree \\
\hline Palaquium ellipticum & 16.79 & 20.5 & 40.01 \\
\hline Cullenia exarillata & 20.16 & 22.5 & 33.53 \\
\hline Mesua ferrea & 28.57 & 20.5 & 14.41 \\
\hline Dysoxylum malabaricum & 21.5 & 6.16 & 5.175 \\
\hline Vateria indica & 9.346 & 14.5 & 21.12 \\
\hline Drypetes venusta & 6.685 & 7.65 & 16.64 \\
\hline Syzygium laetum & 22.2 & 11.2 & 4.967 \\
\hline Agrostistachys borneensis & 6.469 & 13.5 & 12.46 \\
\hline Dimocarpus longan & 6.377 & 7.74 & 12.24 \\
\hline Drypetes malabarica & 10.78 & 6.38 & 10.68 \\
\hline Aglaia tomentosa & 13.73 & 23.53 & 8.632 \\
\hline Antidesma montanum & 4.085 & 6.75 & 7.607 \\
\hline Holigarna nigra & 2.032 & 3.32 & 7.584 \\
\hline Myristica malabarica & 1.517 & 12.1 & 7.253 \\
\hline Turpinia malabarica & 4.693 & 4.22 & 6.582 \\
\hline
\end{tabular}




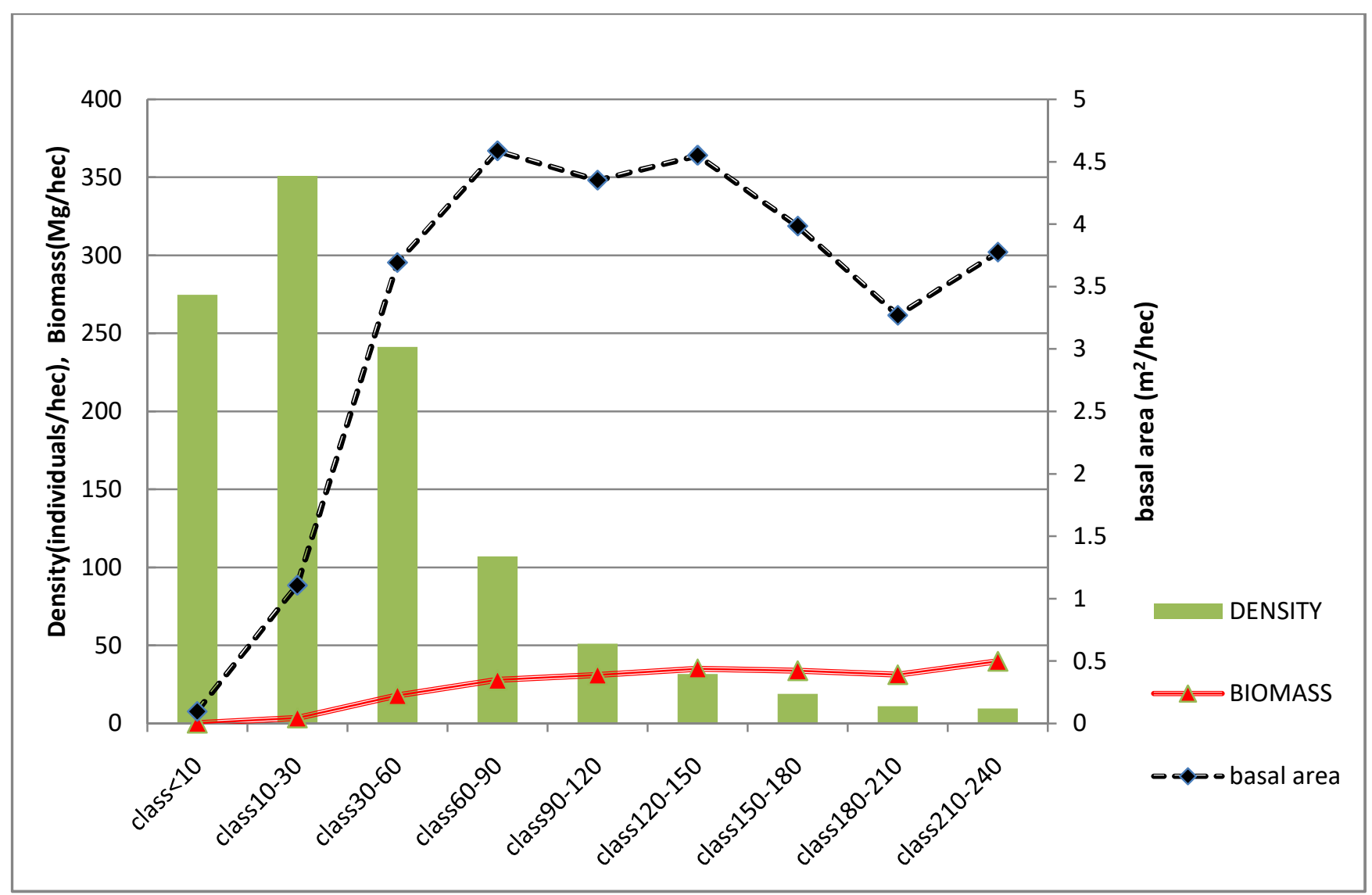

FIGURE 2: Changes in density, Biomass, basal area across different girth classes 


\section{$\underline{\text { Discussion }}$}

Information regarding the floristic composition and diversity of a forest is essential for the ecological research and management. Floristic inventories are prerequisites for constructing the forest models and species distribution patterns. Present study reports the enormous floral diversity of the Sholayar region of southern Western Ghats._According to the family important value index(FIV) that the family Rubiaceae (FIV=44.87) was the most dominant family followed by Sapotaceae (FIV=27.23) and Malvaceae(FIV=25.43). The analysis of the flora of the study area showed that. Rubiaceae was the most represented family followed by Euphorbiaceae and Urticaceae. High densities of Rubiaceae and Euphorbiaceae were also reported from various tropical rain forests (Reynal 1994, ifo 2015).

Although there have been some sound effort in recent past towards long-term monitoring of Western Ghats. Small diameter trees from the evergreen forest of western Ghats received very less attention and they remain under studied. The current study plot is the only one in the Western Ghats' wet evergreen region where smaller diameter woody plants (gbh $\geq 3.14 \mathrm{~cm})$ were included and completely censused. When compared to other evergreen Asian plots the present study plot has moderate proportion of small diameter woody plants (78.67\%) which is above $90 \%$ for most of the wet evergreen tropical plots. The basal area and biomass were concentrated in the large diameter class, which affects the ability of the forest to recover from disturbance affecting the large diameter trees. Large diameter trees store bulk of biomass, which is an agreement with previous forest inventories across tropics (Lee et al. 2002). Decreasing the minimum diameter limit to $1 \mathrm{~cm}$, as opposed to the $10 \mathrm{~cm}$ limit adopted in most evergreen forest tree surveys, revealed a dense and diverse understory. Advantages of incorporating small diameter woody individuals for sampling forest diversity, dynamics, and demography were revealed by Davies et al. 2021. Similar conclusions can be made from our study. Capturing dynamics in the species diversity is one among the key objectives of long term monitoring of ecosystem. Results from the present study demonstrate that contributions of smaller diameter plants are essential for assessing the diversity of the forest.

The species richness of the present 10 hec permanent plot is relatively good when compared to other large-scale permanent plots (Davies et al. 2021) from southern Western Ghats. Tree density in the sholayar plot was very low when compared to other plots across tropics. For plants with $\mathrm{dbh} \geq 10$ it is comparable with other permanent plots in Western Ghats and has 
relatively moderate density of woody plants (541 individuals/ha):447 individuals/ha in Varagaliar site and 763 individuals $\mathrm{ha}^{-1}$ in Uppangala, central western Ghats India. Around $50 \%$ of the species in the plot were treelets that achieve reproductive maturity in the forest under story and rarely attain $10 \mathrm{~cm}$ dbh. The small diameter trees also comprised of seedlings and saplings of all other understory and canopy tree species that do regenerate. When considering plant families more than $50 \%$ of basal area and biomass were concentrated in four families Malvaceae, Sapotaceae, dipterocarpaceae and calophyllaceae. The treelet species richness of total 54 species in the 10-ha plot reflect a high treelets diversity status of tropicalwet evergreen forest of Western ghats. Fishers $\alpha$ value among life form varies as treelets > under story>lower canopy>upper canopy: this trend is an indication of increasing dominance and decreasing species richness from treelet layer to higher canopy layer. The greater density and species richness in the treelets layer might be the consequences of the high rain fall, soil fertility and higher incidence of endozoochory (Thomas 1999)

Our results showed the Simpson and Shannon diversity index of treelets are lower than under story layer this is because of the higher uniformity of individual distribution among species and higher density. It is evident that at girth class 2 Shannon diversity indices for treelets is higher than that of the other life form this is probably due to increased rarity for treelets in girth class 2. Treelets layer of the plot contribute more to the species richness of both diameter class.

\section{$\underline{\text { Regeneration }}$}

The regeneration pattern of the species is shown in Table Girth class analysis of the species suggests that dominant species of the tree layer are failed to maintain its dominance in sapling layer and seedling layer. Density of tree species in seedling and sapling layer is crucial because regeneration status of tree species of any forest is determined by recruitment of saplings and seedlings (Singh and Singh 1992, Dharet al. 1997). The species that are currently dominates in tree layer have relatively lower density and dominance in the seedling and sapling class which indicate that, regeneration of these species are affected and in future growth and dominance of these species may effected in the forest. This kind of regeneration dynamics eventually changes the diversity and stand structure of the forest. In seedling layer along with Mesua ferrea, Syzygium laetum and Dysoxylum malabaricum dominates in both density and IVI indicates a strong evidence to the regeneration dynamics of the tropical wet evergreen forest. The density values of seedlings and saplings are considered as regeneration potential of the species and presence of good regeneration potential shows suitability of a 
species to the environment (Saxena and Singh 1984). From the density curve (Figure 2) it is obvious that in tree species density at initial girth class ( seedling) is lower than the sapling class indicates an unstable regeneration. Climatic factors and biotic interference influence the regeneration of different species in the vegetation (Saha 2016).

\section{Acknowledgement}

We thank the Director and former directors, Kerala Forest Research Institute for providing all facilities for the completion of the study. We acknowledge the help of chief wildlife warden, Kerala Forest Department, Govt. of Kerala for field permission and all forest officials including DFO, Vazhachal Forest Division and Forest Range Officer, Sholayar range for their support. We also aknowledge the Kerala Council for Science, Technology, and Environment (KSCSTE).

\section{$\underline{\text { Reference }}$}

Ayyappan, N. and Parthasarathy, N., 1999. Biodiversity inventory of trees in a large-scale permanent plot of tropical evergreen forest at Varagalaiar, Anamalais, Western Ghats, India. Biodiversity \& Conservation, 8(11), pp.1533-1554.

Blundo, C., Carilla, J., Grau, R., Malizia, A., Malizia, L., Osinaga-Acosta, O., Bird, M., Bradford, M., Catchpole, D., Ford, A. and Graham, A., 2021. Taking the pulse of Earth's tropical forests using networks of highly distributed plots. Biological Conservation, p.108849.

Bradford, M. and Murphy, H.T., 2019. The importance of large-diameter trees in the wet tropical rainforests of Australia. Plos one, 14(5), p.e0208377.

Champion, H.G. and Seth, S.K., 1968. A revised survey of the forest types of India. Manager of publications.

Chave, J., Coomes, D., Jansen, S., Lewis, S.L., Swenson, N.G. and Zanne, A.E., 2009. Towards a worldwide wood economics spectrum. Ecology letters, 12(4), pp.351-366.

Chave, J., Réjou-Méchain, M., Búrquez, A., Chidumayo, E., Colgan, M.S., Delitti, W.B., Duque, A., Eid, T., Fearnside, P.M., Goodman, R.C. and Henry, M., 2014. Improved allometric models to estimate the aboveground biomass of tropical trees. Global change biology, 20(10), pp.3177-3190.

Condit, R., 1998. Tropical forest census plots: methods and results from Barro Colorado Island, Panama and a comparison with other plots. Springer Science \& Business Media.

Curtis, J.T. and Mcintosh, R.P., 1950. The interrelations of certain analytic and synthetic phytosociological characters. Ecology, 31(3), pp.434-455. 
Davies, S.J., Abiem, I., Salim, K.A., Aguilar, S., Allen, D., Alonso, A., Anderson-Teixeira, K., Andrade, A., Arellano, G., Ashton, P.S. and Baker, P.J., 2021. ForestGEO: Understanding forest diversity and dynamics through a global observatory network. Biological Conservation, 253, p.108907.

Dhar, U., Rawal, R.S. and Samant, S.S., 1997. Structural diversity and representativeness of forest vegetation in a protected area of Kumaun Himalaya, India: implications for conservation. Biodiversity \& Conservation, 6(8), pp.1045-1062.

Feldpausch, T.R., Lloyd, J., Lewis, S.L., Brienen, R.J., Gloor, M., Monteagudo Mendoza, A., Lopez-Gonzalez, G., Banin, L., Abu Salim, K., Affum-Baffoe, K. and Alexiades, M., 2012. Tree height integrated into pantropical forest biomass estimates. Biogeosciences, 9(8), pp.3381-3403.

Gamble, J. S., \& Fischer, C. E. C. (1915-1935). Flora of the Presidency of Madras, Parts I to XI. London, UK: Secretary of State for India.

Hérault, B. and Piponiot, C., 2018. Key drivers of ecosystem recovery after disturbance in a neotropical forest. Forest Ecosystems, 5(1), pp.1-15.

Hooker, J.D., 1872. The Flora of British India, Vol. 1. The Flora of British India, Vol. 1.

Ifo, A.S., Koubouana, F., Jourdain, C. and Nganga, D., 2015. Stock and flow of carbon in plant woody debris in two different types of natural forests in Bateke Plateau, Central Africa. Open Journal of Forestry, 5(01), p.38.

Kenfack, D., Thomas, D.W., Chuyong, G. and Condit, R., 2007. Rarity and abundance in a diverse African forest. Biodiversity and Conservation, 16(7), pp.2045-2074.

Lutz, J.A., Furniss, T.J., Johnson, D.J., Davies, S.J., Allen, D., Alonso, A., Anderson-Teixeira, K.J., Andrade, A., Baltzer, J., Becker, K.M. and Blomdahl, E.M., 2018. Global importance of large-diameter trees. Global Ecology and Biogeography, 27(7), pp.849-864.

Lutz, J.A., Furniss, T.J., Johnson, D.J., Davies, S.J., Allen, D., Alonso, A., Anderson-Teixeira, K.J., Andrade, A., Baltzer, J., Becker, K.M. and Blomdahl, E.M., 2018. Global importance of large-diameter trees. Global Ecology and Biogeography, 27(7), pp.849-864.

Memiaghe, H.R., Lutz, J.A., Korte, L., Alonso, A. and Kenfack, D., 2016. Ecological importance of small-diameter trees to the structure, diversity and biomass of a tropical evergreen forest at Rabi, Gabon. PloS one, 11(5), p.e0154988.

Nayar TS, Rasiya Beegam A \& Sibi M (2014) Flowering plants of the Western Ghats India. JNTBGRI, Tiruvananthapuram, pp. 265-266. 
Pascal, J.P. and Ramesh, B.R., 1987. A field key to the trees and lianas of the evergreen forests of the Western Ghats (India). Travaux de la section scientifique et technique. Institut français de Pondichéry, 23.

Réjou-Méchain, M., Tanguy, A., Piponiot, C., Chave, J. and Hérault, B., 2017. biomass: an $\mathrm{r}$ package for estimating above-ground biomass and its uncertainty in tropical forests. Methods in Ecology and Evolution, 8(9), pp.1163-1167.

Saha, S., Rajwar, G.S. and Kumar, M., 2016. Forest structure, diversity and regeneration potential along altitudinal gradient in Dhanaulti of Garhwal Himalaya. Forest systems, 25(2), p.2.

Sasidharan, N. (2004). Biodiversity Documentation for Kerala Part 6: Flowering Plants. Kerala Forest Research Institute, Peechi, 193 pp.

Sasidharan, N., 2012. Flowering plants of Kerala-Version 2.0 DVD No. 14. Kerala Forest Research Institute, Peechi.

Saxena, A.K. and Singh, J.S., 1984. Tree population structure of certain Himalayan forest associations and implications concerning their future composition. Vegetatio, 58(2), pp.61-69.

Saxena, A.K., Singh, S.P. and Singh, J.S., 1984. Population structure of forests of Kumaun Himalaya: implications for management. Journal of Environmental Management, 19(4), pp.307-324.

Sukumar, R., Dattaraja, H.S., Suresh, H.S., Radhakrishnan, J., Vasudeva, R., Nirmala, S. and Joshi, N.V., 1992. Long-term monitoring of vegetation in a tropical deciduous forest in Mudumalai, southern India. Current Science, pp.608-616.

Tiwari, O.P., Rana, Y.S., Krishan, R., Sharma, C.M. and Bhandari, B.S., 2018. Regeneration dynamics, population structure, and forest composition in some ridge forests of the Western Himalaya, India. Forest science and technology, 14(2), pp.66-75. 